\title{
Analysis of Law Principle of the Agreement Substance between State Coorporation with Farmers
}

\author{
${ }^{1}$ Abdul Rahim, ${ }^{2}$ Paisal Halim \\ ${ }^{1}$ Faculty of Law, ${ }^{2}$ Post Graduate Program \\ ${ }^{1}$ Universitas Indonesssia Timur, Makassar, South Sulawesi, Indonesia \\ ${ }^{1}$ Institut IlmuSosial dan Manajemen STIAMI, Jakarta, Indonesia
}

\begin{abstract}
The research aims to describe the substance of the agreement between enterprises with farmers in South Sulawesi. This is the qualitative research and focusing of applicable law principle in agreement. The aggreement between PTPN XIV (one of state own enterprises in Indonesia) and the farmers was the research subject. This research obtained 20 farmers and employees of PTPN XIV as informant. The research concluded the partnership pattern between the company and the farmers was the empowermentprocess of the community around the business unit. The agreement elaborated of rights and obligations of company and farmers. The legal principle contained in the agreement is principle of freedom, pact-sunt servanda principle, principle of fariness, good faith principle and principle of trust.
\end{abstract}

IndexTerms - Contract law, empowerment and agreement.

\section{INTRODUCTION}

Legal rules as the base of agreementgive legitimacy to cooperation between the two parties of deal maker. Legal principles define the limits or range of applicability of the rule of law. Justification or legitimacy of the binding force of a treaty should be sought and tested principles underlying the law. The clauses of an agreement which comes from the agreement of the parties that make it, in principle, are the rules that bind those who make it.[1].

In the Indonesian Criminal Code (KUHP) Article, 1338 revealed that civil essentially affirms that any agreements made and agreed upon by the parties by the laws binding as law for those who make it. This rule implies that when the clause agreements made and agreed upon by the parties, at the same time the inherent rights and obligations are reciprocal to be fulfilled or implemented.

The principle which states that an agreement freely made by the parties and has the force of law and binding on all parties who made it. It is accepted and recognized as a principle in contract law. Then, legal agreements made and agreed upon by the parties who made it must be founded and by the legal principles underlying that has application to power tie. [2].

Issues arising whether the clause that becomes the substance of the agreement have agreed that it is appropriate or not by the principles in force of contract law. Hence the importance of the clauses of an agreement that has been agreed is tested on the principles of law overriding. To guarantee the truth and for the sake of the interests of its interpretation, then the strength of binding clauses agreed arrangement was highly dependent on compliance with the legal principles underlying.

Legal principles it is the crystallization of positive laws. Legal principles it contains ethical values, the value of truth and even the religious values that must be obeyed and respected by the parties to agree. If there is a clause in the agreement made ignoring the legal principles underlying, can indeed be detrimental to the party who made it. The principles of contract law mean that consensual principle, the principle of freedom of contract, the principle of pact sunt-servanda, the principle of good faith, the principle of public interest (Article 1338 and 1339 of KUHP). The fifth principle is a pillar that must be fulfilled in each contract. Besides in Indonesia is also known legal principles national agreement, namely: the principle of trust, fairness, the principle of morality, merit, the principle of habit, the principle of equality before the law, the principle of legal certainty, the principle of balance and the principle of protection.[3].

The own state enterprises which are operating the plantation of agribusiness business of rubber, palm oil, tea, and sugar cane commodities.In its operations, the company has a partnership with farmers in plantation area. The agreement between PTPN XIV with smallholders on Oil Palm Plantations in South Sulawesi Province has been ongoing since 1983/1984 which is located North Luwu and East Luwu. The legally binding relationship between PTPN XIV by smallholders are public relations through treaties.This study aims to assess the suitability of the legal principle on the substance of the agreement between the state enterprise with farmers.

\section{RESEARCH METHOD}

This study aims to reveal the substance of the agreement between enterprises with farmers in South Sulawesi. This type of research is qualitative descriptive. The informants of research were farmers and employee The data analysis divided into three stages that reduction, display, and conclusion. The researchers conducted triangulation for credibility and confirmability of data.

\section{RESUlt AND DISCUSSION}

\section{Cooperation and Community Partnership Activities}

PTPN XIV is conducting partnership programs with farmers with the aim of developing a community economy based on their potential and participation roles. Another goal is to establish a professional, entrepreneurial spirit so that people have economic 
independence.The Indonesian government initiated the implementation of a partnership between state-owned enterprises and the public in 1992. The basis of the policy is Law No. 12/1992 on Plant Culture System. This policy requires business entities to cooperate in an integrated manner with farming. With such regulation, business entities can develop community potentials in industrial activities based on plantation activities.

In the cooperation agreement between the company and the farmers outlined the rights and obligations of two parties, namely:

- The company provides partnership fund to the farmers as the capital for the procurement of oil palm seedlings ready for planting.

- Farmers are required to prepare a Statement of Debt Recognition.

- Farmers must sell the results of fresh fruit bunches to the company by applicable quality standards.

The company provides services to farmers in the form of technical guidance of cultivation in the form of formal guidance conducted through annual training routine. In addition the company provides non-formal guidance is done through visits by the company that served in the area of farmers.

The results of the study indicated that the farmers who are part of the program feel the benefits of engagement with the company. Firstly, the benefit is the existence of company assistance throughout the cultivation of oil. Farmers can consult with counterparts on pest problems, fertilization, harvesting activities and post-harvest activities. Secondly, the quality of fresh fruit bunches is a requirement that must be met by farmers. To achieve quality, farmers and field technical facilitators monitor fruit development intensively. Good quality affects the increasing of selling price and can direct the community has the economic independence of society. Thirdly, the attachment between farmers and companies affects the social forces of society. If there is a conflict between the two parties, then the community spontaneously look for the cause of the problem so that the conflict is not widespread.

\section{Substance of the Agreement}

The results of the study on agreements between companies and farmers indicate that the contents of the agreement by the Civil Code (KUHP) by table 1

Table 1. The Substance of Agreement

\begin{tabular}{|l|l|}
\hline \multicolumn{1}{|c|}{ Principle } & \multicolumn{1}{c|}{ Substance in KUHP } \\
\hline Freedom of contract & $\begin{array}{l}\text { Article 1338 paragraph (1) } \\
\text { and paragraph (3). } \\
\text { Article 1337 } \\
\text { Article 1339 Article 1347 }\end{array}$ \\
\hline Pact-suntservanda principle & $\begin{array}{l}\text { Article 1338, paragraph (1) } \\
\text { and article 1374 }\end{array}$ \\
\hline The principle of fairness & Article 1338, paragraph (3) \\
\hline The principle of good faith & Article 1338, paragraph (3) \\
\hline The principle of trust & Article 1337 \\
\hline
\end{tabular}

PTPN XIV managing community land in North Luwu and East Luwu of South Sulawesi for oil palm plantation activities. Some communities of Luwu Utara and East Luwu districts manage oil palm plantations and are willing to cooperate with PTPN XIV. Palm oil commodities have an excellent economic outlook for 15 years. The growth of land area in this area increased and resulted in increased productivity. (Table 2)

Table 2. Area and production of oil palm in Luwu Utara

\begin{tabular}{|c|c|c|}
\hline Year & Area (Ha) & Productivity (ton) \\
\hline 2011 & 12.657 & 69.879 \\
\hline 2012 & 14.644 & 84.670 \\
\hline 2013 & 16.892 & 92.882 \\
\hline
\end{tabular}

Informant outlines some facts about the suitability of implementation with the legal principle.The principle of freedom of contract associated with the view that the contract is the result of free choice or both parties are free to determine the terms stipulated in the contract. In this study, farmers and state enterprises have the opportunity to manage the contents of the agreement.However, the reality shows that farmers are not involved in contracting. The farmer does not even have the right to request changes to the contents of the agreement.

The pacta sunt servanda principle civil law or common law. This principle determines that private individuals have the freedom to determine the content and legal effect of a contract without any interference and restriction by law. The fairness principle means that all parties involved in the agreement benefit and similar expenses. Corporations profit in plantations, while farmers also benefit from its activities as well as improved welfare. Based on this research, farmers considered that the agreement between the company and the farmers do notbenefit. So the need for legal communications to provide opportunities both parties in disclosing the weakness of the agreement. 


\section{Discussion}

Contracts of cooperation between companies and farmers in general can benefit farmers and companies. Therefore, both parties must practice the rights and obligations of both parties. Farmers and companies are not allowed to take actions that hinder the achievement of the objectives of the agreement. The legal principle of Pact-sunt servanda as the basic norm of the implementation of the agreement shall be accepted by the farmer for the duration of the contract's term. However, the government acting as a control agent must monitor the implementation of such cooperation.

\section{Conclusion}

Based on the results of research and discussion presented above, it can be concluded that the partnership pattern between the company and the farmers was the empowermentprocess of the community around the business unit. The agreement elaborated on rights and obligations of company and farmers. The legal principle contained in the agreement is theprinciple of freedom, pactsuntservanda principle, principle of fairness, good faith principle and principle of trust.

\section{REFERENCES}

[1] K. W. Abbott, R. O. Keohane, A. Moravcsik, A.-M. Slaughter, and D. Snidal, "The concept of legalization,” Int. Organ., vol. 54, no. 3, pp. 401-419, 2000.

[2] J. Goldstein, M. Kahler, R. O. Keohane, and A.-M. Slaughter, "Introduction: Legalization and world politics," Int. Organ., vol. 54, no. 3, pp. 385-399, 2000.

[3] S. J. Shapiro, "Law, morality, and the guidance of conduct," Leg. Theory, vol. 6, no. 2, pp. 127-170, 2000. 